\title{
INFLUENCE OF SOIL TREATMENT METHODS AND FERTILIZER SYSTEMS ON PRODUCTIVITY OF GRAIN-GRAND TREATMENT IN CONDITIONS OF THE CENTRAL CISCAUCASIA
}

\author{
Vladimir Trukhachev, Alexander Esaulko, Maxim Sigida, Sergey Korostylev, Valentin Ageev \\ Stavropol State Agrarian University, Russia, Russia \\ rector@stgau.ru, aesaulko@yandex.ru, sigida@list.ru,korostylev16@mail.ru
}

\begin{abstract}
The article gives a comparative assessment of the impact of various fertilizer systems and soil tillage methods on the productivity of crop rotation and the economic effectiveness of using fertilizer systems within the framework of the SSAU long-term station. Since 1976, in the field crop rotation of the permanent station, the influence of systematic annual complex application of fertilizers, soil treatment methods on the productivity of agricultural crops of 8 fields rotation and the fertility of leached chernozem have been studied. Held between 1978 and 2018, the research has shown that the studied fertilizer systems and methods of tillage give the crop rotation sustainable productivity, preserve and increase the soil fertility, and predetermine the increasing productivity trend. On leached chernozem, moldboard and nonmoldboard methods of tillage to a depth of 20$22 \mathrm{~cm}$ are recommended, as ensuring optimal agrochemical soil condition, maximum productivity of crop rotation and the highest economic effect. The saturation of crop rotation with organic fertilizers gave the soil significant moisture storage functions: lower limit of $5 \mathrm{t} \cdot \mathrm{ha}^{-1}$ of manure, from which the moisture storage functions of leached chernozem began to be optimized, regardless of the methods of placing scraps in the soil; the upper limit ( 7.5 or more $\left.t \cdot \mathrm{ha}^{-1}\right)$, the effectiveness of which was determined by the methods and the depth of placement of the scraps in the soil. In order to preserve the soil fertility to obtain the average annual productivity of grain cultivation crop rotation 3.5-4.4 th $\mathrm{ha}^{-1}$ grain unit, a biologized fertilizer system with a saturation of $1 \mathrm{ha}$ of the crop rotation area $\mathrm{N} 43 \mathrm{P} 20 \mathrm{~K} 0+9.0 \mathrm{t} \cdot \mathrm{ha}^{-1}$ of organic fertilizers is recommended, and for obtaining programmable crop yields and crop productivity of 4.5-5.3 tha $\mathrm{ha}^{-1}$ grain unit, a fertilizer design system with a saturation of 1 ha of the crop rotation area N86P74K11 + 5.0 th ha ${ }^{-1}$ of manure is preferred.
\end{abstract}

Keywords: fertilizers, processing, productivity, crop rotation.

\section{Introduction}

With systematic long-term use of fertilizers, the physical properties of the soil and its chemical composition do not remain constant. Depending on the set of crops, the genetic properties of the soil, the doses of mineral and organic fertilizers, use of soil improvers, the soil fertility becomes better to some degree. Irrational land exploitation leads to a decrease in the soil fertility [1-3].

Changes in the soil affect the crop yields and the effectiveness of fertilizers with their further use. It is known that soils more cultivated (with less acidity, greater saturation with bases, with a higher content of mobile forms of phosphorus and potassium, with higher nitrification capacity, better physical properties, etc.) give higher yields of all agricultural crops. This is confirmed by a number of short-term and long-term experiments. Improving or at least preserving the soil fertility as the main factor determining high and stable yields is given much attention [4-8].

At the same time, there are concerns related to the possible negative impact of fertilizers, pesticides and other means of chemicalization on the environment elements. Excessively high doses of mineral fertilizers without sufficient scientific substantiation, violation of their use technology, intensive tillage using a heavy machine-tractor fleet, and other factors predetermine the complex of possible negative environmental consequences. Mankind faces the problem of further agricultural development and searches for alternative ways to maintain its high productivity $[9 ; 10]$.

In this regard, a decrease in the use of mineral fertilizers, a reduction in the sources of traditional forms of organic fertilizers and worsening of the ecological situation require a new approach to solving the problem of reproducing the soil fertility and increasing the productivity of arable land [11].

The currently proposed ways to solve this problem are expedient and to a large extent realizable. Biological farming is based on a number of fundamental factors: crop rotations, adaptive species and varieties of field crops, differentiated tillage, expansion of perennial legume grasses sowing, biologized fertilizer system based on minimal use of industrial chemicals and widespread introduction of traditional and non-traditional organic fertilizers, biological products [12]. 
The geographical network of experiments with fertilizers is the most important direction in the development of agrochemical research, the scientific basis for developing methods for reproducing the soil fertility and increasing the productivity of domestic agriculture [13].

In this regard, the purpose of the research is to study the effects of soil treatment methods and fertilizer systems on the productivity of grain cultivation under the conditions of Central Ciscaucasia. The tasks of the research included: 1) to establish the relationship between the productivity of crop rotation and agrochemical indicators of leached chernozem; 2) to determine the impact of soil treatment on the fertility of crop rotation from 1978 to 2018 (5 rotations).

\section{Materials and methods}

Since 1976, in the field crop rotation of the permanent study area (station), the influence of systematic annual complex application of fertilizers, soil tillage methods on the productivity of agricultural crops of 8 fields crop rotation and the fertility of leached chernozem have been studied. From the start of the experiment in nature, the station has undergone modifications, and more than 18 conceptual changes have been implemented in it, caused by the state of science and the experimentation technology. The unstable economic situation of the 1990s made an adjustment, when, due to the disparity of prices for industrial and agricultural products, the cost of mineral fertilizers and other means of chemicalization increased to such proportions that they became difficult to access for most agricultural enterprises. Under these conditions the search for less expensive fertilizer systems were of particular interest, and therefore, since 1999, it was decided to optimize the fertilizer systems in crop rotation studied earlier, based on the data obtained in the station for 1976-1999 (Table 1).

Table 1

Scheme of the stationary experience

\begin{tabular}{|c|c|c|c|c|c|c|}
\hline \multirow{3}{*}{$\begin{array}{c}\text { Methods and } \\
\text { techniques of tillage } \\
\text { (for each fertilizer } \\
\text { system) }\end{array}$} & \multicolumn{6}{|c|}{ Years of study / Duration of observation } \\
\hline & $\begin{array}{l}\text { 1st rotation } \\
(1978-1985)\end{array}$ & $\begin{array}{l}\text { 2nd rotation } \\
(1986-1993)\end{array}$ & $\begin{array}{c}\text { Aftereffect of } \\
\text { fertilizer systems } \\
\text { (1994-1999) }\end{array}$ & $\begin{array}{l}\text { 3rd rotation } \\
(2000-2007)\end{array}$ & $\begin{array}{l}\text { 4th rotation } \\
(2008-2015)\end{array}$ & $\begin{array}{l}\text { 5th rotation } \\
(2016-2018)\end{array}$ \\
\hline & \multicolumn{6}{|c|}{ Fertilizer system saturation of crop rotation NPK $(\mathrm{kg} / \mathrm{ha})+$ manure $\left(\mathrm{t} \cdot \mathrm{ha}^{-1}\right)$} \\
\hline \multirow{4}{*}{$\begin{array}{l}\text { 1. Moldboard } \\
\text { 2. Nonmoldboard } \\
\text { 3. Rotatory (different } \\
\text { depths since 2000) } \\
\text { 4. Surface }\end{array}$} & \multicolumn{2}{|c|}{$\begin{array}{l}\text { Control (without } \\
\text { fertilizer) }\end{array}$} & \multirow{4}{*}{$\begin{array}{c}\text { Fertilizers are not } \\
\text { used. }\end{array}$} & \multicolumn{3}{|c|}{ Control (without fertilizer) } \\
\hline & \multicolumn{2}{|c|}{ Recommended $60+2.5$} & & \multicolumn{3}{|c|}{ Recommended $115+5,0$} \\
\hline & \multicolumn{2}{|c|}{ Balance $120+5.0$} & & \multicolumn{3}{|c|}{ Biologized $63+9,0$} \\
\hline & \multicolumn{2}{|c|}{ Computational $180+7.5$} & & \multicolumn{3}{|c|}{ Computational $171+5,0$} \\
\hline
\end{tabular}

Permanent study area (station) of the Stavropol State Agrarian University is located on the Stavropol Upland, according to the scheme of agro-climatic regionalization of the Stavropol Territory in the zone of unstable humidification. The average long-term amount of precipitation is $551 \mathrm{~mm}$, during the growing season it falls $350-370 \mathrm{~mm}$, the average annual air temperature is $9.2^{\circ} \mathrm{C}$. The hydrothermal coefficient is 1.1-1.3. The soil of the experimental plot is leached chernozem, powerful, medium humus loamy, which is currently characterized by an average content of humus (5.2-5.9\%), nitrification capacity (16-30 mg $\mathrm{kg}^{-1}$ ), mobile phosphorus (18-28 $\mathrm{mg} \cdot \mathrm{kg}^{-1}$ according to Machigin), and increased - exchangeable potassium (240-29 $\left.\mathrm{mg} \cdot \mathrm{kg}^{-1}\right)$. The reaction of the soil solution in the upper soil horizons is neutral, $\mathrm{pH}$ is in the range of 6.2-6.7.

With respect to the control (without fertilizers), since 2000, we have studied the following fertilizer systems: the recommended fertilizer system with a crop rotation saturation of NPK $115 \mathrm{~kg} \cdot \mathrm{ha}^{-1}$ including $\mathrm{N}_{50} \mathrm{P}_{59} \mathrm{~K}_{6}$ with the ratio $\mathrm{N}: \mathrm{P}: \mathrm{K}=1: 1.18: 0.13+5 \mathrm{t} \cdot \mathrm{ha}^{-1}$ of manure; the biologized fertilizer system - focused on maximum use of organic fertilizers with a crop rotations saturation of $63 \mathrm{~kg} \cdot \mathrm{ha}^{-1}$, including $\mathrm{N}_{43} \mathrm{P}_{20} \mathrm{~K}_{0}$ at the ratio $\mathrm{N}: \mathrm{P}: \mathrm{K}=1: 0.47: 0+9 \mathrm{t} \cdot \mathrm{ha}^{-1}$ of organic fertilizers, including $5 \mathrm{t} \cdot \mathrm{ha}^{-1}$ of litter manure; the computational fertilizer system is planned to obtain the maximum possible yield of agricultural crops (pea-oat mixture $-33 \mathrm{t} \cdot \mathrm{ha}^{-1}$, winter wheat $-6.5 \mathrm{t} \cdot \mathrm{ha}^{-1}$, winter barley $-5.5 \mathrm{t} \cdot \mathrm{ha}^{-1}$, corn for silage $-55 \mathrm{t} \cdot \mathrm{ha}^{-1}$, winter wheat $-5.5 \mathrm{t} \cdot \mathrm{ha}^{-1}$, peas $-3.3 \mathrm{t} \cdot \mathrm{ha}^{-1}$, winter wheat - 
$6 \mathrm{t} \cdot \mathrm{ha}^{-1}$, sunflower $\left.-3 \mathrm{t} \cdot \mathrm{ha}^{-1}\right)$. The norms of the ratio and dose of mineral fertilizers were established according to the results of current analyzes and plant diagnostics in accordance with the level of the programmed yield based on the method of V.V. Ageeva (1979) and A.N. Esaulko (2006), and annually refined. The average saturation of 1 hectare during the research period (2000-2015) was $171 \mathrm{~kg} \cdot \mathrm{ha}^{-1}$ of NPK including $\mathrm{N}_{83} \mathrm{P}_{76} \mathrm{~K}_{12}$ at the ratio N:P:K = 1:0.92:0.14 + $5 \mathrm{t} \cdot \mathrm{ha}^{-1}$ of manure.

Since 2000, the variants with the fertilizer systems studied according to the scheme of experience have been superimposed on the variants with different methods of basic tillage: 1 - moldboard method (plowing to a depth of 20-22 cm, mounted adjustable plough (ПHР $(3+1) ; 2$ - different depths (plowing under peas, pea-oat mixture, winter barley to a depth of 20-22 cm; combined soil tillage with combined unit for minimal tillage (AKM-4.2) for winter wheat after its forecrops, peas and pea-oat mixture to a depth of 16-18 cm; disking with disk tiller (БДМ 6×4) for winter wheat after its forecrops, maize for silage to a depth of 10-12 cm; deep nonmoldboard loosening (chiseliness) with mounted chisel plough (ПЧН-4) for sunflower and maize to a depth of 30-35 cm); 3 - combined (tillage to a depth of 16-18 cm, with combined unit for minimal tillage (AKM - 4.2); 4 - surface tillage (disking to a depth of 10-12 cm, with the disk tiller (БДМ 6×4).

The arrangement of variants in repetitions is systematic sequential in two tiers with split plots. The type of crop rotation is grain cultivated with the following crop alternation: pea-oat mixture (seeded fallow) - winter wheat, winter barley, maize for silage, winter wheat, pea, winter wheat, sunflower, deployed in space and time. The total area of the plot $-108 \mathrm{~m}^{2}$, declared area $-60 \mathrm{~m}^{2}$. Triple repetition of the experiment. The total area of the station is 6.4 ha.

Analysis and processing of the obtained results were carried out according to generally accepted methods.

\section{Results and discussion}

Long field experiments constitute the basic unit of the whole system of experiments in agrarian science. The achievement of the Russian agrarian science is the stationary departments of agrochemistry and physiology of plants and general and ameliorative farming - "Theoretical and technological flows of biogeochemical substances in agricultural landscapes". It was founded in 1976 by Professor Ageev V.V. and Academician of the Russian Academy of Sciences Penchukov V.M.

The stationary department experienced four modifications and updates, there were difficult times, but it has been preserved and continues to function. Already since its foundation, the station differed from its foreign and domestic predecessors in the polyfactorial scheme, i.e. at the same time, the study of fertilizer systems, monocultures, 8-field crop rotation, developed in space and time, and methods of basic tillage began. The experience distinguishes the dynamism of agrotechnology, which is regularly improved. The obtained results of this experience are of fundamental importance for the whole agrochemical science and obtaining practical experience in understanding the theory of plant nutrition.

The researches held between 1978 and 2018 have shown that the fertilizer systems being studied give the crop rotation a sustainable productivity, preserve and increase the fertility of the soil, predetermine the increasing trend of productivity.

Fundamental developments include theoretical substantiation of biogeochemical fluxes in agrolandscapes. So, we determined the effect of the long-term use of soil fertility mobilization on the translocation of macro and microelements, heavy metals in the system soil - fertilizer - plant. The influence of natural and anthropogenic factors on the content of elements in various components of the agroecosystems of the Central Ciscaucasia has been studied. Methodical and methodological approaches to conducting ecological and agrochemical monitoring during long-term experiments are proposed.

Relationships have been established between the crop productivity and agrochemical indicators of leached chernozem, the presented regression equations allow adjusting the dose of organic and mineral fertilizers: $Y=4.82 \times 1+0.91 \times 2-19.25$. Regardless of the fertilizer system, the content in the $0-20 \mathrm{~cm}$ soil layer of mineral nitrogen has a decisive influence on the productivity of crop rotation. With an increase in the saturation of 1 ha of arable land with mineral and organic fertilizers (calculated and balance - biologized fertilizer systems), the productivity of crop rotation determines the main agrochemical indicators: 
- balance (biologized) fertilizer system

$$
=9.49 \times 1+1.37 \times 2-0.15 \times 4+8.94 \times 5-80.6
$$

- calculating fertilizer system

$$
=7.48 \times 1+1.76 \times 2-1.45 \times 3+0.11 \times 4-4.02 \times 5-28.14,
$$

where $\mathrm{Y}$ - productivity of crop rotation, $\mathrm{t} \cdot \mathrm{ha}^{-1}$ grain unit;

$x 1$ - humus content in the $0-20 \mathrm{~cm}$ soil layer, \%;

$x 2$ - mineral nitrogen content in the $0-20 \mathrm{~cm}$ soil layer, $\mathrm{mg} \cdot \mathrm{kg}^{-1}$;

$x 3$ - labile phosphorus content in the $0-20 \mathrm{~cm}$ soil layer, $\mathrm{mg} \cdot \mathrm{kg}^{-1}$;

$x 4$ - content of exchangeable potassium in the $0-20 \mathrm{~cm}$ soil layer, $\mathrm{mg} \cdot \mathrm{kg}^{-1}$;

$x 5$ - reaction of the soil solution in the $0-20 \mathrm{~cm}$ soil layer.

The productivity of grain cultivation is represented in grain units. Grain unit is an indicator used for equivalent comparison of different types of crop production. Grain is taken as the basic unit of measurement, the products of other agricultural crops (technical, vegetable, etc.) are converted into comparable products according to the ratio of their yield to the crop yield (over a number of years). The conversion factors to the grain unit are: winter wheat is 1 , sunflower is 1.47 , peas is 0.99 , pea-oat mixture is 0.14 , corn for silage is 0.17 , they are used in the preparation of long-term plans for crop production.

Optimization of fertilizer systems was carried out by us through the use of computational methods for determining the rates of fertilizers for the programmable productivity of crop rotation, the distribution of fertilizers according to the fertilizer methods and biologization of the fertilizer systems. The ratio $\mathrm{N}: \mathrm{P}: \mathrm{K}$ in the fertilizer systems under the influence of the computational methods changed from 1:1.23:0.45 (1978) to 1:0.92:0.14 (2015), on the biologized system - from 1:1.28:0.39 to 1:0.47:0, which had a different impact on the optimization of the soil agrochemical properties.

The saturation of crop rotation with organic fertilizers gave the soil significant moisture storage functions: the lower limit of $5 \mathrm{t} \cdot \mathrm{ha}^{-1}$ of manure, from which the moisture storage functions of leached chernozem began to be optimized, regardless of the methods of placing mineral fertilizers in the soil; the upper limit ( 7.5 or more $\left.t \cdot \mathrm{ha}^{-1}\right)$, the effectiveness of which was determined by the methods and the depth of placement of the mineral fertilizers in the soil.

With regard to productivity for the practice of modern agriculture, the biologized and computational fertilizer systems are the most perspective, depending on the level of the economy (Table 2).

Four-decade-old, obtained on the natural agrochemical background in connection with the study of the tillage methods, clearly indicates a diminishing trend in the productivity of the actual rotation. In 1978-2018 methods of processing natural agrochemical background formed almost equal productivity of crop rotation, with the exception of surface tillage, which reduced this indicator by $0.26-0.65 \mathrm{t} \cdot \mathrm{ha}^{-1}$ grain unit.

The thirty-eight-year data, obtained on the natural agrochemical background in connection with the study of tillage methods, clearly indicate a diminishing trend in the productivity of the actual rotation. In 1978-2015 methods of processing natural agrochemical background formed almost equal productivity of crop rotation, with the exception of surface tillage, which reduced this indicator by $0.26-0.65 \mathrm{t} \cdot \mathrm{ha}^{-1}$ grain unit.

By 2018, the greatest effect was obtained from the interaction of fertilizer systems and soil treatment methods on the fertilizer calculation system (N86P74K11 +5.0 t $\cdot \mathrm{ha}^{-1}$ of manure) in combination with the moldboard method of tillage $-5.21 \mathrm{t} \cdot \mathrm{ha}^{-1}$ grain unit at depths of $5.51 \mathrm{t} \cdot \mathrm{ha}^{-1}$ grain unit. The increase in the use of the biologized fertilizer system (N43P20K0 $+8.8 \mathrm{t} \cdot \mathrm{ha}^{-1}$ of organic fertilizers) compared with the control was significant $\left(1.01 ; 0.73 ; 1.21\right.$ and $0.93 \mathrm{t} \cdot \mathrm{ha}^{-1}$ grain unit), and the level crop rotation productivity is equal to that obtained from applying the recommended fertilizer system (N50P59K6 $+5 \mathrm{t} \cdot \mathrm{ha}^{-1}$ of manure).

A low-cost biologized fertilizer system for grain-cultivated crop rotations based on the efficient use of organic fertilizers, local application of minimum doses of mineral fertilizers is proposed. These works have made a significant contribution to the establishment of the basic principles for the 
construction of biologized fertilizer systems and the development of rational methods of tillage in the unstable wetting zone of the Central Ciscaucasia. The regularities of the agrochemical properties of the meter profile of chernozem and chestnut soils are established depending on the time factor, the improvement of fertilizer systems and physical methods of changing soil fertility.

Table 2

Productivity of grain cultivation in the conditions of Central Ciscaucasia

\begin{tabular}{|c|c|c|c|c|c|c|c|}
\hline \multirow{3}{*}{$\begin{array}{c}\text { Fertilizer system } \\
\text { NRK crop } \\
\text { rotation } \\
\text { saturation } \\
\left(\mathrm{kg}^{\circ} \mathbf{h a}^{-1}\right) \\
+ \text { manure }^{-1} \\
\left(\mathrm{t} \cdot \mathrm{ha}^{-1}\right), \mathrm{A} \\
\end{array}$} & \multirow{3}{*}{$\begin{array}{c}\text { Method } \\
\text { (techniques) of } \\
\text { tillage, B }\end{array}$} & \multicolumn{6}{|c|}{ Productivity, $t \cdot h^{-1}$ grain unit } \\
\hline & & \multicolumn{2}{|c|}{ rotations } & \multirow{2}{*}{$\begin{array}{c}\text { Aftereffect } \\
\text { of fertilizer } \\
\text { systems } \\
(1994- \\
1999)\end{array}$} & \multicolumn{3}{|c|}{ rotations } \\
\hline & & $\begin{array}{c}\text { 1-st (1978 } \\
1985)\end{array}$ & $\begin{array}{c}\text { 2-nd } \\
\text { (1986- } \\
1993)\end{array}$ & & $\begin{array}{c}\text { 3-rd } \\
(2000- \\
2007)\end{array}$ & $\begin{array}{l}\text { 4-th } \\
(2008- \\
2015)\end{array}$ & $\begin{array}{c}\text { 5-th } \\
\text { (2016- } \\
2018)\end{array}$ \\
\hline \multirow{4}{*}{ Control } & Moldboard & 3.57 & 3.54 & 2.72 & 3.23 & 3.40 & 3.44 \\
\hline & Different depths & 3.34 & 3.42 & 2.66 & 3.09 & 3.46 & 3.61 \\
\hline & Combined & 3.44 & 3.40 & 2.62 & 2.99 & 3.01 & 3.32 \\
\hline & Surface & 3.19 & 3.15 & 2.46 & 2.82 & 2.75 & 2.88 \\
\hline \multirow{4}{*}{$\begin{array}{c}\text { Recommended } \\
60+2.5 \\
(1978-1993) \\
115+5.0 \\
(2000-2015) \\
\end{array}$} & Moldboard & 3.92 & 3.90 & 2.87 & 4.03 & 4.51 & 4.66 \\
\hline & Different depths & 3.64 & 3.77 & 2.80 & 3.76 & 4.27 & 4.89 \\
\hline & Combined & 3.74 & 3.71 & 2.79 & 3.66 & 3.95 & 4.60 \\
\hline & Surface & 3.46 & 3.51 & 2.63 & 3.36 & 3.62 & 4.11 \\
\hline \multirow{4}{*}{$\begin{array}{c}\text { Balance } 120+5 \\
(1978-1993) \\
\text { Biologized } \\
63+8.8 \\
(2000-2015)\end{array}$} & Moldboard & 4.11 & 4.12 & 3.13 & 3.98 & 4.40 & 4.45 \\
\hline & Different depths & 3.85 & 3.96 & 3.02 & 3.72 & 4.12 & 4.34 \\
\hline & Combined & 3.94 & 3.96 & 3.01 & 3.64 & 3.87 & 4.03 \\
\hline & Surface & 3.61 & 3.71 & 2.79 & 3.33 & 3.49 & 3.81 \\
\hline \multirow{4}{*}{$\begin{array}{c}\text { Computational } \\
180+7,5 \\
(1978-1993) \\
171+5.0 \\
(2000-2015) \\
\end{array}$} & Moldboard & 4.25 & 4.11 & 3.25 & 4.52 & 5.33 & 5.21 \\
\hline & Different depths & 3.97 & 3.92 & 3.17 & 4.22 & 5.01 & 5.51 \\
\hline & Combined & 4.07 & 3.93 & 3.16 & 4.14 & 4.50 & 5.00 \\
\hline & Surface & 3.74 & 3.66 & 2.91 & 3.85 & 4.07 & 4.52 \\
\hline \multicolumn{2}{|c|}{$\mathrm{HCP}_{05, \text { tha }}$} & 0,30 & 0.32 & 0.19 & 0.23 & 0.32 & 0.36 \\
\hline
\end{tabular}

In order to obtain a programmable crop yield and crop rotation productivity, the method of calculating the rates of fertilizers by V.V. Ageev in our modification is preferable; the coefficients of using nutrients from soil and fertilizers by plants are specified in the process of conducting scientific and production research. Approbation of the method of calculating fertilizer systems for programmable crop rotation was carried out in agricultural enterprises of the Stavropol Territory and adjacent territories of the Central Ciscaucasia on an area of 130-180 thousand hectares with an average annual economic effect of 3800-6200 rubles from 1 ha. The calculation of economic indicators in the prices of 2018 showed that the optimization of fertilizer systems (2000-2018) contributed to the increase in the economic efficiency and the most effective for the fifth rotation of the crop rotation (2016 -2018) were low-cost biologized and highly productive calculated fertilizer systems.

\section{Conclusions}

1. The moldboard method of tillage to a depth of 20-22 mass media is recommended on the leached chernozem, as it provides an optimal agrochemical condition of the soil, maximum productivity of crops in crop rotation and the highest economic effect.

2. The biologized fertilizer system with a saturation of 1 ha of the crop rotational area $\mathrm{N} 43 \mathrm{P} 20 \mathrm{KO}+9.0 \mathrm{t} \cdot \mathrm{ha}^{-1}$ of organic fertilizers is recommended in order to preserve the soil fertility, to obtain the average annual productivity of grain cultivating crop rotation $4.34-4.45 \mathrm{t} \cdot \mathrm{ha}^{-1}$ grain unit, and to obtain the planned level of the crop yields and crop productivity of 5.21-5.51 $\mathrm{t} \cdot \mathrm{ha}^{-1}$ 
grain unit. The fertilizer computational system with a saturation of 1 ha of the crop rotation area $\mathrm{N} 86 \mathrm{P} 74 \mathrm{~K} 11+5.0 \mathrm{t} \cdot \mathrm{ha}^{-1}$ of manure in combination with the moldboard and different depths methods of tillage is preferred.

\section{References}

[1] Esaulko A.N., Voskoboinikov A.V., Galda D.E., Oleynikov A.Y., Ozheredova A.Y. Improving The Nutrition Of Non-Traditional Leguminous Crops For The Conditions Of The Central Ciscaucasia. Research journal of pharmaceutical biological and chemical sciences. V. 9. I. 6. , 2018. pp. 1911-1915.

[2] Esaulko A.N., Sigida M.S., Golosnoy E.V., Ozheredova A.Y., Korostylev S.A. Management Of Nitrogen Fertilizing Of Winter Wheat In No-Till Technology. Research journal of pharmaceutical biological and chemical V. 9. I. 6., 2018. pp. 1916-1920.

[3] Song, K., Zheng, X., Lv, W., Qin, Q., Sun, L. Zhang, H. Xue, Y. Effects of tillage and straw return on water-stable aggregates, carbon stabilization and crop yield in an estuarine alluvial soil. Scientific Reports 9(1), 2019, 4586.

[4] Pöhlitz, J., Rücknagel, J., Schlüter, S., Vogel, H.-J., Christen, O.Computed tomography as an extension of classical methods in the analysis of soil compaction, exemplified on samples from two tillage treatments and at two moisture tensions. Geoderma 346, 2019.pp. 52-62.

[5] Sithole, N.J., Magwaza, L.S., Thibaud, G.R. Long-term impact of no-till conservation agriculture and $\mathrm{N}$-fertilizer on soil aggregate stability, infiltration and distribution of $\mathrm{C}$ in different size fractions. Soil and Tillage Research 190, 2019.pp. 147-156.

[6] Tskhovrebov V.S., Kalugin D.V., Faizova V.I. Nikiforova A.M., Mar'in A.N. Change in Microbiological Indicators With Introduction Of Rocks On Chernozem Leached. Research journal of pharmaceutical biological and chemical sciences. V. 9. I. 4., 2018 pp. 1153-1158.

[7] Tskhovrebov V.S., Faizova V.I. Nikiforova A.M., Onischenko L.M. Dynamics of cellulolytic microorganisms on the virgin soil and arable chernozems of the central Ciscaucasia. Research journal of pharmaceutical biological and chemical sciences V.8. I.1., 2017 pp. 1857-1861.

[8] Vlasova O.I., Perederieva V.M., Volters I.A., Tivikov A.I., Trubacheva L.V. Change in microbiological activity under the effect of biological factors of soil fertility in the central ForeCaucasus chernozems. Biology and Medicine.V. 7. № 5., 2015. pp. 146-150.

[9] Perederieva V.M., Vlasova O.I., Volters I.A., Trubacheva L.V., Shutko A.P. Dynamics of agrofito-cenosis segetal' flora of winter wheat in long-term soil treatment. Research Journal of Pharmaceutical, Biological and Chemical Sciences. V. 8. № 6., 2017. pp. 782-786.

[10] Vlasova O.I., Perederieva V.M., Volters I.A., Drepa E.B., Danilets E.A. Previous crop - as an element of organic farming in the cultivation of winter wheat in the central Fore-Caucasus. Research Journal of Pharmaceutical, Biological and Chemical Sciences. V. 9. № 6., 2018. pp. 1272-1276.

[11]Tskhovrebov V.S., Faizova V.I., Mar'in A.N., Kalugin D.V., Novikov A.A., 2016. Document Changing population by aerobic nitrogen-fixing bacteria in natural and anthropogenically transformed chernozems biogeocenoses Central Ciscaucasia. Source of the Document Research Journal of Pharmaceutical, Biological and Chemical Sciences, 7 (4) : pp. 2178-2182.

[12] Gamzikov G.P. Status and prospects of research in long-term stationary experiments with fertilizers in Siberia // Fertility. 2016. № 5 (92). pp. 6-9.

[13] Sychev V.G., Belichenko M.V., Romanenkov V.A. Stages of development, research results and actual problems of long-term agrochemical field experiments of a geographic network, fertilizers experiments / Agrochemistry. 2018. No. 1. pp. 3-16. 